\title{
(2) OPEN ACCESS \\ Social innovation in health: a critical but overlooked component of the COVID-19 pandemic response
}

\author{
Patricia Moscibrodzki (D) , ${ }^{1}$ Jingjing Li, ${ }^{2}$ Rosanna W Peeling (D) ,' \\ Beatrice Halpaap (D) , ${ }^{3}$ Luis Gabriel Cuervo (D) , ${ }^{4}$ Magaly M Blas (D) , \\ Noel Juban (D), ${ }^{6}$ Meredith Labarda (i) , 7 Weiming Tang (D) , \\ Joseph D Tucker (1) ${ }^{1,9}$
}

For numbered affiliations see end of article.

\section{Correspondence to} Dr Patricia Moscibrodzki, London School of Hygiene and Tropical Medicine Faculty of Infectious and Tropical Diseases, London WC1E 7HT, UK; Patricia. Moscibrodzki@|shtm.ac.uk

PM and JL contributed equally.

Accepted 26 May 2021 Published Online First 17 June 2021
D) Check for updates

(C) Author(s) (or their employer(s)) 2021. Re-use permitted under CC BY-NC. No commercial re-use. See rights and permissions. Published by BMJ.

To cite: Moscibrodzki P, Li J, Peeling RW, et al. BMJ Innov 2021;7:523-525.

\section{BACKGROUND}

The COVID-19 pandemic has profoundly disrupted the provision of health services across the globe. Travel to hospitals is restricted and many health facilities have limited services, deepening financial problems for some clinics and hospitals. ${ }^{1}$ Vulnerable groups who are already marginalised by their gender, race or nationality have been disproportionately affected by COVID-19..$^{2}$ In response, social innovations have been developed to protect vulnerable groups and rapidly pivot health systems towards COVID-19. Social innovations in health are inclusive solutions that meet the needs of end users through a multistakeholder, communityengaged process to address the healthcare delivery gap. ${ }^{3}$ Social innovation is particularly well suited for the COVID-19 response because it focuses on local needs, develops low-cost solutions and builds on community strengths (figure 1). In partnership with partner academic institutions, the Special Programme for Research and Training in Tropical Diseases launched the Social Innovation in Health Initiative (SIHI) in 2014. SIHI focuses on research, training and advocacy related to social innovation in health. In collaboration with partners, the network organised an online open event to discuss social innovation responses to emergencies. ${ }^{4}$ This piece highlights how social innovation has contributed to the COVID-19 response and presents three examples of social innovation projects that have adapted to the pandemic. These examples demonstrate how social innovation during COVID-19 has mobilised local communities, swiftly adapted existing health services and built strong partnerships.

\section{COMMUNITY MOBILISATION IN PERU}

COVID-19 responses suggest the importance of local community mobilisation and the flexibility of projects that may already be operating in the field to improve other health outcomes. Mamás Del Río is a community-based maternal and neonatal health programme operating in 84 remote Amazon communities in Peru and 30 communities on the PeruvianColombian border (figure 2). Local people are selected through community assemblies and receive training to become community health workers. The instructional focus is on traditional birth attendant support, strengthening healthcare facilities and comprehensive supervision. Empowered with a tablet application, the community health workers conduct home visits to pregnant women and their families, deliver health educational content and gather data to share with local government. ${ }^{5}$ During COVID-19 travel restrictions, the communities in the implementation area became isolated and health facilities suspended routine services. The programme rapidly adapted to meet the needs of local people, including delivery of materials and equipment for basic COVID-19 prevention, managing misconceptions through phone supervisions, developing video training for community health workers about COVID-19 and continuing home visits for people with COVID-19 symptoms. ${ }^{6}$ Since the start of the pandemic until December 2020, community health workers have conducted 1113 visits to 
Social innovation focuses on local needs and priorities.

Ongoing community mobilization as part of social innovation projects can be rapidly adapted for COVID-19 responses.

Digital social innovations (e.g., Chipatala Cha Pa Foni) can be used to enhance COVID-19 communications.

Multi-sectoral collaboration developed through social innovation can address social determinants of health.

The strong focus on equity and people-centeredness provides ways to strengthen COVID-19 responses for vulnerable groups.

Figure 1 Characteristics of social innovation that have facilitated its use during the COVID-19 pandemic.

pregnant women and provided 270 safe delivery kits. The project enabled the community to sustain maternal and neonatal health services while responding to urgent needs of the COVID-19 pandemic.

\section{ADAPTING EXISTING SERVICES IN MALAWI}

Adapting existing social innovations to shifting needs during the wake of a crisis can be effective in driving service uptake. Chipatala Cha $\mathrm{Pa}$ Foni, or Health Centre by Phone, is a toll-free health hotline in Malawi that provides health information and referrals on demand. The innovation was driven by the realisation that people in Malawi, especially those at the last mile, travel long distances to the nearest health facility to receive access to information. The hotline was iteratively co-created with local people to provide health advice, demonstrated to be effective, and then scaled up nationwide. ${ }^{7}$ In response to COVID-19, the government leveraged the platform's capabilities to triage people with COVID-19 symptoms, identify and refer people experiencing violence, and clarify shelterin-place policies. The hotline is now the official way to reach healthcare workers and get answers to COVID19-related questions in Malawi. Between April and June of 2020 , approximately $30 \%$ of all calls to the

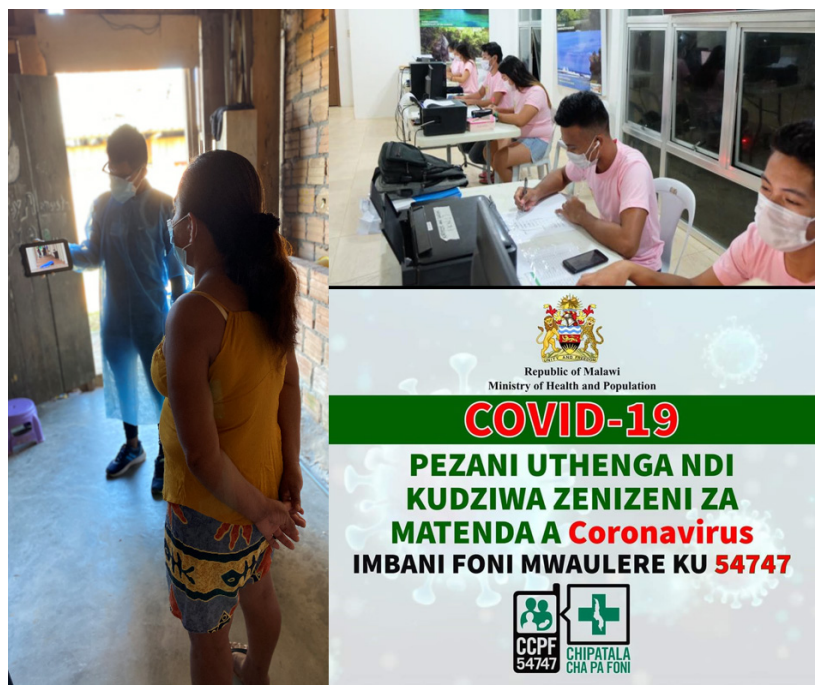

Figure 2 Social innovations responding to COVID-19 in Peru (left), Philippines (top right) and Malawi (bottom right). hotline were related to COVID-19. ${ }^{8}$ The communitydriven access to free, timely, reliable and quality health information has enabled adaptation during the COVID-19 response. The hotline has provided a mechanism for the Ministry of Health to better understand local needs during the COVID-19 pandemic.

\section{MULTISECTORAL PARTNERSHIP IN THE PHILIPPINES}

Multisectoral partnership is another key engine in driving sustainable social innovation programmes during COVID-19. The Seal of Health Governance is a multisectoral health partnership established in the Municipality of Del Carmen in the Philippines that empowers community leaders to ensure quality implementation and sustainability of health programmes. ${ }^{9}$ In 2012, the Del Carmen government joined a partnership with Zuellig Family Foundation and the University of the Philippines to co-create its health reform agenda and provide leadership and governance training to local leaders. This innovative multisectoral partnership brings together the strengths and resources from the private sector, academia and local government. In response to the COVID-19 pandemic, the local government of Del Carmen took action early and fast, rolling out an agenda that not only prevented local outbreak but also maintained local livelihoods. The specific points of focus were on addressing food shortages, ensuring continuum of services at the local health systems level and reducing COVID-19 risk. In response to the needs voiced by the community, through government and private sector partnership, a hunger management campaign on farming and sustainable fishing enabled distribution of food rations to 5000 of the most vulnerable families. A call centre was established to manage the entry of returning residents and prepare the local health system's absorptive capacity. Taking into consideration the local context, both seaborne and land control were in place to administer COVID-19 testing and manage necessary quarantines. Training local leaders and promoting meaningful community participation in solving their own health problems helped the local government prepare and respond to COVID-19 challenges.

\section{SOCIAL INNOVATION DURING COVID-19}

Many social innovations emerged in response to COVID-19 and have helped to address the healthcare delivery gaps in emergency settings through mobilising communities, adapting existing innovations and leveraging multisectoral partnerships. However, few of these programmes have been monitored or evaluated. A Social Innovation in Health Monitoring and Evaluation Framework ${ }^{10}$ and a Social Innovation in Health Research Checklist can help to increase rigour of social innovation research. ${ }^{11}$ More research is needed to examine the process and outcomes of social innovation in health during health emergencies. The 
United Nations General Assembly Resolution 71/276 12 describes resilience as the ability of a system, community or society exposed to hazards to resist, absorb, accommodate to and recover from the effects of a hazard in a timely and efficient manner, including through the preservation and restoration of its essential basic structures and functions. Social innovation initiatives provide powerful means of mobilising communities to respond to emergencies that can complement and extend government and private sector responses and build more resilient societies.

\section{Author affiliations \\ ${ }^{1}$ Department of Clinical Research, London School of Hygiene and Tropical Medicine Faculty of Infectious and Tropical Diseases, London, UK \\ ${ }_{2}^{2}$ Social Entrepreneurship to Spur Health, Guangzhou, China \\ ${ }^{3}$ TDR, the Special Programme for Research and Training in Tropical Diseases Co-sponsored by UNICEF, UNDP, the World Bank and WHO, hosted at WHO, Geneva, Switzerland \\ ${ }^{4}$ Pan American Health Organization, Washington, District of Columbia, USA ${ }^{5}$ Universidad Peruana Cayetano Heredia, Facultad de Salud Publica y Administracion Carlos Vidal Layseca, Lima, Peru \\ ${ }^{6}$ Department of Clinical Epidemiology, University of the Philippines Manila, Manila, Philippines \\ ${ }^{7}$ University of Philippines Manila - School of Health Sciences, Leyte, Philippines \\ ${ }^{8}$ University of North Carolina Project-China, Guangzhou, China \\ ${ }^{9}$ IGHID, University of North Carolina at Chapel Hill, Chapel Hill, North Carolina, USA}

\section{Twitter Joseph D Tucker @JosephTucker}

Acknowledgements We would like to thank Ana Gerlin Hernandez Bonilla and Alfredo M Coro for comments on an earlier version of this manuscript. The work received support from the TDR, the Special Programme for Research and Training in Tropical Diseases co-sponsored by UNICEF, UNDP, the World Bank and WHO. TDR is able to conduct its work thanks to the commitment and support from a variety of funders. These include our long-term core contributors from national governments and international institutions, as well as designated funding for specific projects within our current priorities. For the full list of TDR donors, please visit TDR's website at https://www.who.int/tdr/about/funding/ en/. TDR receives additional funding from Sida, the Swedish International Development Cooperation Agency, to support SIHI. The ideas expressed in this correspondence are the authors' own and do not necessarily reflect the decisions and policies of the TDR or the Pan American Health Organization. Special thanks to Mamas del Rio for their support.

Contributors PM, JL and JDT conceived of the presented idea. PM, JL and JDT wrote the manuscript with input from all authors.

Funding The authors have not declared a specific grant for this research from any funding agency in the public, commercial or not-for-profit sectors.

Competing interests None declared.

Patient consent for publication Not required.

Provenance and peer review Commissioned; externally peer reviewed.

Open access This is an open access article distributed in accordance with the Creative Commons Attribution Non Commercial (CC BYNC 4.0) license, which permits others to distribute, remix, adapt, build upon this work non-commercially, and license their derivative works on different terms, provided the original work is properly cited, appropriate credit is given, any changes made indicated, and the use is non-commercial. See: http://creativecommons.org/ licenses/by-nc/4.0/.

\section{ORCID iDs}

Patricia Moscibrodzki http://orcid.org/0000-0002-4754-1213

Rosanna W Peeling http://orcid.org/0000-0001-7404-8873

Beatrice Halpaap http://orcid.org/0000-0001-8854-2813

Luis Gabriel Cuervo http://orcid.org/0000-0003-2732-5019

Magaly M Blas http://orcid.org/0000-0002-3008-1695

Noel Juban http://orcid.org/0000-0003-2727-4733

Meredith Labarda http://orcid.org/0000-0001-6563-3042

Weiming Tang http://orcid.org/0000-0002-9026-707X

Joseph D Tucker http://orcid.org/0000-0003-2804-1181

\section{REFERENCES}

1 STAT. Hospitals are busier than ever - and going out of business. Available: https://www.statnews.com/2020/05/26/ hospitals-are-busier-than-ever-and-going-out-of-business/ [Accessed 14 Oct 2020].

2 The Lancet. Redefining vulnerability in the era of COVID-19. Available: https://www.thelancet.com/journals/lancet/article/ PIIS0140-6736(20)30757-1/fulltext [Accessed 06 Oct 2020].

3 Halpaap BM, Tucker JD, Mathanga D, et al. Social innovation in global health: sparking location action. Lancet Glob Health 2020;8:e633-4.

4 Mérieux Foundation. SIHI partners workshop: creating an enabling environment for social innovation in health, 2013. Available: https://www.fondation-merieux.org/en/events/ sihi-partners-workshop-creating-an-enabling-environment-forsocial-innovation-in-health/ [Accessed 08 Dec 2020].

5 Reinders S, Alva A, Huicho L, et al. Indigenous communities' responses to the COVID-19 pandemic and consequences for maternal and neonatal health in remote Peruvian Amazon: a qualitative study based on routine programme supervision. BMJ Open 2020;10:e044197.

6 Innovations in Healthcare. Learning and action network: workforce development and remote training during the COVID-19 pandemic|. Available: https://www.innovationsi nhealthcare.org/learning-and-action-network-workforcedevelopment-during-the-pandemic/ [Accessed 11 Jan 2021].

7 Blauvelt C, West M, Maxim L, et al. Scaling up a health and nutrition Hotline in Malawi: the benefits of multisectoral collaboration. BMJ 2018;363:k4590.

8 CHWI. How a health Hotline is supporting frontline health workers during COVID-19, 2020. Available: https://chwi. jnj.com/stay-informed/how-a-health-hotline-is-supportingfrontline-health-workers-during-covid-19 [Accessed 08 Dec 2020].

9 Social Innovation in Health Initiative. Seal of health governance. Available: https:/socialinnovationinhealth.org/ case-studies/seal-of-health-governance/ [Accessed 20 Dec 2020].

10 TDR. Social innovation in health monitoring and evaluation framework. Geneva, Switzerland, 2020.

11 Kpokiri E, Chen E, Li J, et al. Social innovation research checklist: a crowdsourcing open call and digital hackathon to develop a checklist for research to advance social innovation in health. medRxiv 2020. doi:10.1101/2020.11.03.20225110. [Epub ahead of print: 04 Nov 2020].

12 General Assembly of the United nations. Resolutions. Available: https://www.un.org/en/ga/71/resolutions.shtml [Accessed 11 Jan 2021]. 